\title{
RESTYTUCJA, ODSZKODOWANIE CZY INWESTYCJE? - REPRYWATYZACJA MAJĄTKU NIEMIECKIEJ REPUBLIKI DEMOKRATYCZNEJ
}

\begin{abstract}
WSTĘP
Podobnie jak przed innymi krajami byłego bloku wschodniego, tak również przed rządem NRD (a później RFN) stanął problem reprywatyzacji majątków znacjonalizowanych przez państwo lub władze okupacyjne. Proces reprywatyzacji przeprowadzony został w oparciu o cały pakiet aktów prawnych wydanych na przestrzeni lat 1990-1994 i wielokrotnie później nowelizowanych. Niniejszy artykuł przedstawia przebieg tego procesu, zasady przyjęte dla rozwiązania spraw majątkowych oraz ich dalszą ewolucję, a w konsekwencji - istotną zmianę priorytetów przyjętych na początku reprywatyzacji. Celem niniejszego opracowania jest nie tylko prześledzenie historycznych wydarzeń, lecz także znalezienie wskazówek dla uregulowania nadal nierozwiązanej kwestii reprywatyzacyjnej w Polsce. Problem wywłaszczonych przez państwo majątków od ponad 20 lat nie doczekał się ustawowego uregulowania ${ }^{1}$. Dyskusja społeczna pomimo upływu lat nie słabnie, ponadto brak regulacji roszczeń dawnych właścicieli rzutuje istotnie na sposób wykorzystania pokaźnego majątku i stosunki międzynarodowe naszego kraju. Rozważając unormowanie roszczeń reprywatyzacyjnych, warto skorzystać z doświadczeń zachodnich sąsiadów.
\end{abstract}

1 Regulacji prawnej doczekały się jedynie kwestie mienia zabużańskiego - Ustawa $z$ dnia 8 lipca 2005 r. o realizacji prawa do rekompensaty z tytułu pozostawienia nieruchomości poza obecnymi granicami Rzeczypospolitej Polskiej (DzU Nr 169, poz. 1418). Nie jest to, jak sama nazwa wskazuje, regulacja dotycząca mienia znacjonalizowanego przez państwo polskie, lecz odnosząca się do majątku pozostawionego przez Polaków przymusowo wysiedlonych w latach 1944-1952 z terenów należących przed II wojną światową do Polski (tzw. Kresów Wschodnich lub ziem zabużańskich). 


\section{PIERWOTNE USTALENIA}

Uregulowanie spraw wywłaszczonych majątków było jednym z najważniejszych tematów negocjacji, jakie toczyły się wiosną i latem 1990 r. pomiędzy dążącymi do zjednoczenia państwami niemieckimi ${ }^{2}$. Jednocześnie była to bardzo trudna kwestia, zwłaszcza że negocjatorzy musieli wziąć pod uwagę 3 różne okresy wywłaszczeń w historii wschodnich Niemiec ${ }^{3}$. Pierwsze wywłaszczenia nastąpiły w latach 1933-1939 w okresie reżimu nazistowskiego. Następna fala wywłaszczeń dokonana została przez okupacyjne władze radzieckie w latach 1945-1949. Były to wywłaszczenia na szeroką skalę, bez jakiegokolwiek odszkodowania. $Z$ jednej strony stanowiły one rodzaj odwetu za wszczęcie II wojny światowej, z drugiej zaś miały stać się podstawą budowy własności socjalistycznej. ${ }^{4}$ Trzeci etap wywłaszczeń dokonywany był po 1949 r. przez władze byłej NRD.

Poglądy przedstawicieli wschodnich i zachodnich Niemiec różniły się co do zakresu planowanej reprywatyzacji wywłaszczonych majątków. Władze NRD sprzeciwiały się przede wszystkim restytucji mienia skonfiskowanego przez władze radzieckie w okresie 1945-1949. Dla wielu polityków z zachodnich Niemiec takie rozwiązanie było nie do przyjęcia ${ }^{5}$. Ostatecznie jednak zwyciężyła idea kompromisu w imię zjednoczenia obu państw niemieckich i stanowisko NRD zostało zaakceptowane ze względów politycznych.

Pierwsze wyniki prowadzonych negocjacji zostały zawarte we Wspólnej Deklaracji Rządów RFN i NRD w sprawie uregulowania niewyjaśnionych spraw majątkowych z 15 czerwca 1990 r. $^{6} \mathrm{~W}$ deklaracji tej ustalono 14 zasad dotyczących przyszłej, ostatecznej regulacji problemów majątkowych. W pierwszej kolejności przewidziano, że nie zostaną zwrócone majątki wywłaszczone na podstawie prawa wydanego przez okupantów lub w okresie jurysdykcji okupacyjnej w latach 1945-19497. Jak wcześniej wspomniano, uwzględniono więc w tym zakresie stanowisko strony wschodnioniemieckiej. Dla ofiar konfiskat z lat 1945-1949 nie

2 Por. W. Schäuble, Der Vertrag. Wie ich über die deutsche Einheit verhandelte, Stuttgart 1991, s. 256-262.

3 H.M. Stack, The "Colonization" of East Germany?: A Comparative Analysis of German Privatization, „Duke Law Journal” 1997, vol. 46, s. 1221.

4 Ibidem.

5 W. Schäuble, op. cit., s. 259-260. Wielu mieszkańców NRD przed ponad 40 laty kupiło w dobrej wierze ziemie wywłaszczone wcześniej przez władze radzieckie. W działki te zainwestowali często wszystkie swoje oszczędności, budując domy i dacze. Dlatego władze NRD sprzeciwiały się szczególnie reprywatyzacji tych ziem, podnosząc jednocześnie, że odpowiedzialność za te wywłaszczenia ponoszą całkowicie władze radzieckie (ibidem, s. 260-261).

6 Gemeinsame Erklärung der Regierungen der Bundesrepublik Deutschland und der Deutschen Demokratischen Republik zur Regelung offener Vermögensfragen, 15. Juni 1990, BGB1. 1990 II, s. 1237 -1238 .

Zob. punkt 1 Wspólnej Deklaracji. 
przewidziano ani restytucji, ani żadnego odszkodowania. Majątki zabrane w czasie okupacji sowieckiej obejmowały około $1 / 3$ powierzchni NRD ${ }^{8}$. Wyliczono, że zaspokojenie roszczeń majątkowych tych osób kosztowałoby około 8 miliardów marek ${ }^{9}$. Była to poważna suma, której nie udźwignęłoby NRD. Władze RFN nie chciały natomiast, by ich obywatele ponosili nie tylko koszty zjednoczenia, ale też płacili za dawne krzywdy wyrządzone przez władze okupacyjne. Na marginesie należy jednak zauważyć, że suma 8 mld marek niemieckich stanowiłaby zaledwie drobną cząstkę środków, jakie RFN wydało, by pokryć koszty zjednoczenia ${ }^{10}$.

Drugą ważną, jeśli nie najważniejszą, regułą zawartą w deklaracji było stwierdzenie, że co do zasady skonfiskowane nieruchomości zostaną zwrócone ich poprzednim właścicielom albo ich spadkobiercom ${ }^{11}$. Generalnie więc przyjęto we Wspólnej Deklaracji pierwszeństwo restytucji przed rekompensatą pieniężną. Uważano, że zwrot majątków poprzednim właścicielom stanowi najlepszy sposób naprawienia wyrządzonych krzywd. Jak wcześniej wskazano, zasada restytucji nie miała bezwzględnego charakteru, gdyż wyraźnie wyłączono spod jej działania majątki skonfiskowane w okresie okupacji sowieckiej. W teorii zatem zakres planowanej restytucji miał zapewnić stan równowagi pomiędzy dawniej wyrządzonymi krzywdami a aktualnymi potrzebami ekonomicznymi ${ }^{12}$. Okazało się jednak, że przyjęta zasada restytucji pozostawała w jaskrawej sprzeczności z bardziej pilną potrzebą ekonomicznej modernizacji wschodnich Niemiec ${ }^{13}$.

Wspólna Deklaracja została następnie włączona do Traktatu Zjednoczeniowego zawartego 31 sierpnia 1990 przez RFN i NRD ${ }^{14}$. Świadczy to o doniosłości tego zagadnienia w procesie łączenia się dwóch niemieckich państw. Jednocześnie jednak w Traktacie Zjednoczeniowym przewidziano bardzo istotne ograniczenia prawa restytucji wywłaszczonych majątków. Zaznaczono, że zwrotowi nie będą

8 J. Tucker-Mohl, Property Rights and Transitional Justice: Restitution In Hungary and East Germany, http://ocw.mit.edu/courses/urban-studies-and-planning/11-467j-property-rights-intransition-spring-2005/ projects/jtuckermohlfinal.pdf, s. 16 .

9 W. Schäuble, op. cit., s. 256.

10 Szacowane koszty zjednoczenia to ok. 1,5 biliona euro, jakie Niemcy Zachodnie przekazały do 2004 r. nowym krajom związkowym w celu dostosowania wschodnioniemieckiej gospodarki i infrastruktury do poziomu zachodniego (M. Götz, Niemcy w przededniu 20 rocznicy zjednoczenia wciq̨̇̇ różnice?, „Biuletyn Instytutu Zachodniego” 2009, nr 28, s. 2).

11 Punkt 3 Wspólnej Deklaracji (przewidziano również w tym punkcie wyjątki od generalnej zasady).

12 H.M. Stack, op. cit., s. 1221.

13 R. Frank, Privatization in Eastern Germany: A Comprehensive Study, „Vanderbilt Journal of Transnational Law"1994, vol. 27, s. 812.

14 Art. 41 (1) Traktatu pomiędzy RFN i NRD w sprawie przywrócenia jedności Niemiec - Traktat Zjednoczeniowy (Vertrag zwischen der Bundesrepublik Deutschland und der Deutschen Demokratischen Republik über die Herstellung der Einheit Deutschlands-Einigungsvertrag z 31 sierpnia 1990 r., BGB1. 1990 II, S. 903). 
podlegać (na zasadach określonych w oddzielnych aktach prawnych) nieruchomości gruntowe i budynkowe, które są potrzebne dla pilnych celów inwestycyjnych, szczególnie w przypadkach, gdy nieruchomość ma być użyta do utworzenia przedsiębiorstwa produkcyjnego, a realizacja tej inwestycji zasługuje na poparcie $\mathrm{z}$ ekonomicznego punktu widzenia, przede wszystkim gdy tworzy lub chroni miejsca pracy ${ }^{15}$. Traktat Zjednoczeniowy dokonał więc istotnego wyłomu w zasadzie restytucji. W odniesieniu do nieruchomości przeznaczonych do „pilnych celów inwestycyjnych" poprzedni właściciel mógł wystąpić jedynie o odszkodowanie pieniężne.

Traktat Zjednoczeniowy dokonał jeszcze jednej zmiany, istotnej z punktu widzenia niniejszych rozważań. Przewidziano, że art. 135a Konstytucji RFN znajdzie odpowiednie zastosowanie do zobowiązań NRD oraz do zobowiązań RFN, które mają związek z przejęciem wartości majątkowych $\mathrm{NRD}^{16}$. Artykuł ten natomiast przewidywał, ujmując go w dużym uproszczeniu, że ustawodawstwo federalne może przewidywać, iż nie będą w ogóle wypełnione lub nie będą wypełnione w całości zobowiązania byłej Rzeszy. Na mocy więc przepisów rangi konstytucyjnej z góry przewidziano możliwość niewypełnienia w całości roszczeń majątkowych zgłaszanych przeciwko NRD.

\section{USTAWA MAJĄTKOWA - VERMÖGENSGESETZ}

Podstawowym aktem, który określił zasady reprywatyzacji wywłaszczonych majątków, była ustawa o uregulowaniu niewyjaśnionych spraw majątkowych z 23 września 1990 r. - Vermögensgesetz (dalej: ustawa majątkowa) ${ }^{17}$. Akt ten został wydany jeszcze przez władze Niemieckiej Republiki Demokratycznej, a więc państwa, które wcześniej samo dokonywało wywłaszczenia majątków prywatnych na swoją

15 Art. 41 (2) Traktatu Zjednoczeniowego (BGB1. 1990 II, S. 903-904). Inwestor musiał jednak przedłożyć plan wykazujący istotne cechy przedsięwzięcia i zobowiązać się do przeprowadzenia inwestycji na podstawie tego planu.

16 Traktat Zjednoczeniowy dokonał kilku zmian Konstytucji RFN: preambuły, art. 51 i 146. Dodano też art. 143, zgodnie z którym różnice pomiędzy prawem na terenie byłej NRD a konstytucją federalną miały zostać usunięte co do zasady do końca 1992 r. Jednakże art. 41 Traktatu Zjednoczeniowego pozostawał nadal w mocy wraz z regulacjami prawnymi służącymi jego realizacji.

17 Pełna nazwa tego aktu brzmi: Gesetz zur Regelung offener Vermögensfragen (VermG). Dosłownie jest to ustawa o uregulowaniu „otwartych pytań majątkowych” i tak najczęściej tłumaczona jest w języku angielskim jako Statute for the Regulation of Open Property Questions (np. D. Southern, Restitution or compensation: The open property question, „German Politics” 1993, vol. 2, Issue 3, s. 436 i n.). Jedynie H. Mostert podała bardziej „zgrabne” tłumaczenie: Law on the Regulation of Unsolved Property Questions - prawo o regulacji nierozwiązanych pytań majątkowych (eadem, Lost Information and Competing Interests in Restoring Germany`s Dispossessed Property - The Recent Decision of the German Federal Administrative Court, „German Law Journal” 2004, No. 1, s. 4). 
rzecz. Uchwalenie ustawy majątkowej nastąpiło jednak dopiero w przededniu połączenia się Niemiec (a dokładnie przystąpienia niemieckich landów wschodnich, dotychczas tworzących NRD, do RFN), które nastąpiło 3 października $1990 \mathrm{r}$.

Generalna zasada zawarta w $\S 3$ ust. 1 ustawy majątkowej przewidywała, że wartości majątkowe zabrane bezprawnie lub bez odszkodowania byłym właścicielom i następnie włączone do majątku państwowego ${ }^{18}$ lub sprzedane osobom trzecim należy zwrócić uprawnionym na ich wniosek, o ile nie zostało to przez tę ustawę wykluczone. Realizacji tej zasady służył m.in. zakaz dokonywania czynności rozporządzających oraz zaciągania długookresowych zobowiązań umownych w stosunku do nieruchomości, odnośnie do których złożony został wniosek o restytucję, aż do wydania ostatecznej decyzji rozstrzygającej ten wniosek ${ }^{19}$.

W zależności od miejsca położenia majątku uprawniony mógł złożyć wniosek o restytucję lub odszkodowanie do właściwego urzędu. Wszystkie roszczenia oparte na wywłaszczeniach dokonanych w okresie istnienia NRD musiały zostać zgłoszone do 13 października 1990 r. Roszczenia oparte natomiast na wywłaszczeniach dokonanych w okresie rządów nazistowskich musiały zostać zgłoszone do 31 marca $1991 \mathrm{r}$. Po sprawdzeniu roszczenia przez właściwy organ wnioskodawca - o ile spełnił wszystkie wymogi - otrzymywał zaświadczenie, które uprawniało go do zwrotu wywłaszczonego majątku. Wnioskodawca mógł również wybrać odszkodowanie zamiast restytucji - wówczas zaświadczenie stanowiło podstawę do uzyskania kwoty pieniężnej.

W celu ochrony słusznego interesu osób trzecich ustawa majątkowa określiła katalog sytuacji, w których restytucja majątku poprzednim właścicielom była niedopuszczalna, na przykład gdy istotnie zmieniono przeznaczenie lub sposób użytkowania gruntu lub budynku, dokonując dużych nakładów, i nieruchomości te służyły obecnie celowi publicznemu lub gdy własność została nabyta w dobrej wierze $^{20}$ przez osoby fizyczne, organizacje religijne i inne organizacje non-profit ${ }^{21}$. W przypadkach tych uprawnionemu przysługiwało jedynie odszkodowanie pieniężne.

\footnotetext{
18 Dosłownie ustawa posługuje się określeniem Volkseigentum - własność ludowa, społeczna.

$19 \S 3$ (3) ustawy majątkowej. Czynności takie mogły być dokonane za zgodą uprawnionego (wnioskodawcy składającego wniosek o restytucję).

20 Dobra wiara nabywcy została określona szeroko, ponadto przyjęto domniemanie jej istnienia, chyba że prawowity właściciel wykazał, iż obecny posiadacz wiedział albo powinien był wiedzieć, że nabycie nie było zgodne z prawem, uzyskał własność za pomocą korupcji lub użycia osobistych wpływów, oszukał poprzedniego właściciela lub wykorzystał jego przymusową sytuację. Jeśli były właściciel nie mógł wykazać powyższych przesłanek, musiał zadowolić się odszkodowaniem pieniężnym lub zamienną działką gruntu.

${ }^{21} \S 4$ i 5 ustawy majątkowej (Ausschluss der Rückübertragung). Zobacz więcej na ten temat: W.G. Vitzthum, W. März, Restitutionsausschluss, Berlin 1994.
} 
Zgodnie z zasadą przyjętą wcześniej we Wspólnej Deklaracji o restytucję majątku na podstawie ustawy majątkowej mogły się starać jedynie osoby wywłaszczone przed 1945 r. przez władze hitlerowskie lub po 1949 r. przez władze NRD. Spod zakresu regulacji tej ustawy wyłączono natomiast mienie skonfiskowane $\mathrm{w}$ okresie istnienia radzieckiej strefy okupacyjnej. Była to kontrowersyjna regulacja, której zarzucano naruszenie konstytucyjnej zasady równości ${ }^{22}$. Sprawa znalazła swoje rozstrzygnięcie w Federalnym Trybunale Konstytucyjnym ${ }^{23}$, który 23 kwietnia 1991 r. wydał dyskusyjny wyrok utrzymujący w mocy postanowienie Traktatu Zjednoczeniowego, w myśl którego wywłaszczenia $\mathrm{z}$ lat 1945-1949 pozostawały nieodwracalne. Jednocześnie jednak Trybunał stwierdził, iż zasada równości określona w konstytucji wymaga, aby poprzedni właściciele otrzymali pewne odszkodowanie. Dopiero 27 września 1994 r. niemiecki parlament „niechętnie" uchwalił ustawę przewidującą odszkodowania dla osób fizycznych z tytułu majątku wywłaszczonego w latach $1945-1949^{24}$, realizując tym samym decyzję Trybunału ${ }^{25}$.

\section{PRAWO O SZCZEGÓLNYCH INWESTYCJACH}

Wraz z Traktatem Zjednoczeniowym weszło z życie prawo o szczególnych inwestycjach, które normowało dalsze wyjątki od zasady restytucji ${ }^{26}$. Głównym celem nowej ustawy było zrealizowanie innego nadrzędnego zadania określonego w Einigungsvertrag - stymulacji wzrostu gospodarczego ${ }^{27}$. Prawo o szczególnych inwestycjach wprowadziło naczelną zasadę, że pod pewnymi warunkami nieruchomości gruntowe i budynki należące poprzednio do państwa mogły zostać sprzedane przez aktualnego posiadacza, mimo iż został w stosunku do tych nieruchomości złożony wniosek albo nadal mógł zostać złożony przez prawowitego właściciela ${ }^{28}$. Dopuszczalność sprzedaży tego majątku zależała jednak od wystą-

\footnotetext{
22 Art. 3 konstytucji RFN.

23 Bundesverfassungsgericht (BVerfG).

24 Gesetz über staatlische Ausgleichsleistungen für Enteignungen auf besatzungsrechtlicher oder besatzungshoheitlicher Grundlage, die nicht mehr rückgängig gemacht werden können (Ausgleichsleistungsgesetz - AusglLeistG) BGB1. 1994 I, S. 2628. Na temat Ausgleichsleistungsgesetz zob. więcej: H.J. Rodenbach, O. Löffler, Entschädigungen und Ausgleichsleistungen für Vermögensverluste in ehemaligen DDR und der SBZ, Berlin 1995.

25 A. Randelzhofer, C. Tomuschat, State Responsibility and the Individual. Reparation in Instances of Grave Violations of Human Rights, Cambridge 1999, s. 274-275.

26 Gesetz über besondere Investitionen in der Deutschen Demokratischen Republik, Gesetzblatt der Deutschen Demokratischen Republik 1990 I, S. 1897 (dalej: prawo o szczególnych inwestycjach).

27 R. Frank, op. cit., s. 858.

$28 \S 1$ ustawy o szczególnych inwestycjach.
} 
pienia szczególnego celu inwestycyjnego. Zgodnie z tymi przepisami szczególne cele inwestycyjne występowały wówczas, gdy majątek był niezbędny do:

a) zabezpieczenia lub stworzenia miejsc pracy, w szczególności przez utworzenie zakładu przemysłowego lub przedsiębiorstwa usługowego,

b) zaspokojenia w znacznym zakresie potrzeb mieszkaniowych ludności lub

c) rozwijania infrastruktury potrzebnej dla obu lub jednego $z$ wyżej wymienionych celów przy wykorzystaniu konkretnej nieruchomości gruntowej lub budynku' ${ }^{29}$.

Aktualny posiadacz, jeśli chciał dla realizacji wyżej wymienionych celów nabyć nieruchomość, musiał przedstawić plan określający istotne elementy zamierzonych inwestycji ${ }^{30}$. Właściwy organ lokalnej administracji badał ten plan i określał zdolność inwestora do wykonania planowanych działań ${ }^{31}$. Jeśli organ uznał, że aktualny posiadacz jest zdolny do zrealizowania planu, wydawał zaświadczenie dla specjalnych celów inwestycyjnych ${ }^{32}$. Możliwość zakupu nieruchomości na specjalne cele inwestycyjne ograniczono jednak ścisłym terminem - plan inwestycyjny należało przedłożyć do końca $1992 \mathrm{r}^{33}$ Przed wydaniem zaświadczenia organ był zobowiązany przeprowadzić rozprawę, jeśli poprzedni właściciel zgłosił wniosek restytucyjny.

Zaświadczenie inwestycyjne nie mogło zostać wydane, jeśli prawomocny wyrok sądu lub ostateczna decyzja właściwego organu nakazywały zwrot nieruchomości poprzedniemu właścicielowi lub jego spadkobiercom. $Z$ kolei jeśli aktualny posiadacz nieruchomości uzyskał zaświadczenie inwestycyjne, poprzedni właściciel nie mógł już zapobiec sprzedaży tej nieruchomości na cele inwestycji ${ }^{34}$. Przysługiwało mu natomiast żądanie o zapłatę odszkodowania w wysokości dochodów ze sprzedaży nieruchomości albo jej rzeczywistej wartości rynkowej35. Postępowanie w sprawie uzyskania zaświadczenia inwestycyjnego było długotrwałe i skomplikowane, gwarantowało jednak potencjalnemu inwestorowi należyty poziom bezpieczeństwa ${ }^{36}$. Jeśli bowiem inwestor spełnił wymogi związane

$29 \S 1(2)$ a, b i c prawa o szczególnych inwestycjach.

$30 § 1$ (3) prawa o szczególnych inwestycjach.

31 W praktyce w pierwszej kolejności badano dane dotyczące inwestora w odpowiednim rejestrze w celu wykluczenia nierzetelnych podmiotów (W. Försterling, Rechts der offenen Vermögensfragen, München 1993, s. 132).

$32 \S 2$ prawa o szczególnych inwestycjach.

33 Termin ten został następnie na mocy nowej ustawy przedłużony o rok (Das Gesetz zur Beseitigung von Hemmnissen bei der Privatisierung von Unternehmen und zur Förderung von Investitionen z 22 marca 1991 r., BGB1. 1991 I, S. 766).

$34 \quad$ W przypadku, w którym istniały podstawy do unieważnienia zaświadczenia inwestycyjnego i wszczęto odpowiednie postępowanie sądowe lub administracyjne, nowy właściciel nie zostałby wpisany do księgi wieczystej - §2 (4) prawa o szczególnych inwestycjach.

$35 \S 3$ (1) prawa o szczególnych inwestycjach.

36 R. Frank, op. cit., s. 836. 
z uzyskaniem zaświadczenia, mógł podejmować inwestycje bez obaw, że będzie zobowiązany zwrócić nieruchomość poprzedniemu właścicielowi.

Celem wprowadzonych w prawie o szczególnych inwestycjach wyjątków od generalnej zasady restytucji było pobudzenie inwestycji we wschodnich Niemczech. Krótko po zawarciu Traktatu Zjednoczeniowego i wprowadzeniu w życie związanych z nim ustaw okazało się jednak, że wolumen inwestycji prywatnych w byłej NRD nie był wystarczający dla gwałtownej modernizacji gospodarki ${ }^{37}$. Prawo własności większości nieruchomości znajdujących się we wschodnich landach stanowiło kwestię sporną. Ta niepewność sytuacji prawnej znacznej liczby majątków, w stosunku do których roszczenia zgłosili poprzedni właściciele, powodowała, że tempo inwestycji we wschodnich Niemczech pozostawało nadal zbyt niskie ${ }^{38}$. Panujące wówczas nastroje dobrze oddaje wypowiedź burmistrza Lipska, który swą frustrację wyraził następującymi słowami: „Roszczenia dawnych właścicieli blokują cały rozwój ekonomiczny, [...] zamrażają wszystkie plany inwestycyjne" 39 .

Postanowienia prawa o szczególnych inwestycjach okazały się niewystarczające dla gwałtownego pobudzenia inwestycji, zawarte w nim wyjątki od zasady restytucji były zbyt wąsko ujęte i restrykcyjne. Ustawa majątkowa również zawierała kilka wad. Najbardziej odczuwalną z nich był wcześniej wspomniany zakaz dokonywania czynności rozporządzających oraz zaciągania długookresowych zobowiązań umownych, jeśli w stosunku do danej nieruchomości złożony został wniosek o jej zwrot. Ustawodawca starał się więc poprawić sytuację kolejnymi zmianami prawnymi z 1991 i 1992 r., przyspieszającymi procedury dla sprzedaży nieruchomości o potencjale inwestycyjnym.

\section{ZMIANY WPROWADZONE W 1991 R.}

Wiosną 1991 r. uchwalono ustawę o znaczącym tytule - Prawo o usunięciu barier prywatyzacji przedsiębiorstw i wspieraniu inwestycji ${ }^{40}$. Głównym celem nowych przepisów było skorygowanie niedociągnięć ustawy majątkowej i prawa o szczególnych inwestycjach. Nowa ustawa poprawiła pozycję inwestorów, przyznając im przewagę nad osobami występującymi z wnioskami restytucyjnymi. Jej przepisy oznaczały wyraźne odejście, ale nie całkowite porzucenie wcześniejszej polityki

\footnotetext{
37 Ibidem, s. 841.

38 J. Tucker-Mohl, op. cit., s. 17.

39 D. Southern, Restitution or Compensation: The Property Question, [w:] Transitional Justice, red. N.J. Kritz, Washington 1995, s. 644.

40 Cytowana wyżej ustawa: Das Gesetz zur Beseitigung von Hemmnissen bei der Privatisierung von Unternehmen und zur Förderung von Investitionen z 22 marca 1991 r. (BGB1. 1991 I, S. 766).
} 
dotyczącej ochrony praw osób wnoszących skargę restytucyjną. Nowe podejście zostało wyrażone kilkoma istotnymi poprawkami do ustawy majątkowej ${ }^{41}$. Przede wszystkim wprowadzono wyjątek od krytykowanego zakazu dokonywania czynności prawnych w stosunku do nieruchomości, odnośnie do których złożony został wniosek o restytucję, jeśli aktualnym posiadaczem była jednostka państwowa lub Treuhandanstalt (Urząd Powierniczy) ${ }^{42}$. Urząd Powierniczy mógł sprzedać lub wydzierżawić sporną nieruchomość, o ile służyło to rozwojowi inwestycji. Wprowadzenia takiego rozwiązania domagał się wyraźnie Urząd Powierniczy, aby zrealizować powierzone mu zadanie przeprowadzenia szybkiej prywatyzacji ${ }^{43}$. Prawa poprzednich właścicieli ubiegających się o zwrot własności zostały w takich przypadkach podporządkowane prawom osób trzecich zainteresowanych nabyciem majątku, o ile okazałyby się one lepszymi inwestorami. Potencjalny inwestor musiał jednak spełnić wymagania określone w prawie o szczególnych inwestycjach. Ponieważ wprowadzona regulacja istotnie zwiększyła tempo prywatyzacji, nazywano ją ,inwestycyjną autostradą" ${ }^{4}$.

Zmianie uległy też przepisy prawa o szczególnych inwestycjach, które w pierwotnej wersji nie były w stanie wydobyć pełnego potencjału inwestycyjnego gospodarki byłej $\mathrm{NRD}^{45}$. Jak wcześniej wspomniano, przewidziane w ustawie specjalne cele inwestycyjne zostały określone zbyt wąsko, m.in. dlatego, że odnosiły się tylko do nieruchomości gruntowych i budynkowych ${ }^{46}$. W zakresie tego pojęcia nie mieściło się wiele innych, istotnych $\mathrm{z}$ gospodarczego punktu widzenia inwestycji, m.in. dotyczących majątku włączonego do Landwirtschaftliche Produktionsgenossenschaft - odpowiednika polskich PGR-ów. Dlatego też rozszerzono określenie specjalnego celu inwestycyjnego na działania związane z utrzymaniem

41 Vermögensgesetz w wersji z 18 kwietnia 1991, BGB1. I S. 957.

42 Głównym zadaniem Urzędu Powierniczego było dokonanie restrukturyzacji przedsiębiorstw państwowych, przekształcenie ich w kapitałowe spółki prawa prywatnego i w ostatnim stadium ich sprywatyzowanie ( $\$ 2$ Gesetz zur Privatisierung und Reorganisation des volkseigenen Vermögens (Treubandgesetz) z 17 czerwca 1990 r.). Urząd Powierniczy szybko stał się najważniejszą, ale też jednocześnie najbardziej kontrowersyjną instytucją w procesie prywatyzacji. Na przełomie 1994 i 1995 r. Urząd Powierniczy sprywatyzował większość spółek i został rozwiązany - końcowy bilans Urzędu wykazywał całkowitą stratę w wysokości 256 miliardów marek niemieckich (C.M. Frege, Social Partnership at Work. Workplace relations in post-unification Germany, London-New York 1999, s. 38). Bliższa analiza problematyki związanej z działalnością Treuhandanstalt wykracza poza ramy niniejszego opracowania.

43 M.E. Elling, Privatization in Germany: A Model For Legal and Functional Analysis, „Vanderbilt Journal of Transnational Law"1992, vol. 25, Issue 4, s. 612.

44 H. Leo, \$ 3 a Vermögensgesetz - Vorfahrt für Investitionen?, „Der Betrieb”, 19 lipca 1991 r., Heft 29, s. 1505.

45 R. Frank, op. cit., s. 845-846.

46 G. Fieberg, H. Reichenbach, Einführung, [w:] Vermögengesetz, München 2001, s. XXV. 
lub stworzeniem gospodarstwa rolnego i podtrzymaniem produkcji rolnej ${ }^{47}$. Wprowadzono możliwość zawarcia $\mathrm{z}$ aktualnym posiadaczem gospodarstwa rolnego długoterminowych umów dzierżawy i najmu na okres do 12 lat. Było to kolejne odstępstwo od zakazu wynikającego z § 3 (3) ustawy majątkowej. Aktualny posiadacz podlegał jednak wymogom prawa o szczególnych inwestycjach - musiał uzyskać zaświadczenie inwestycyjne i swoimi osobistymi przymiotami gwarantować osobiste prowadzenie gospodarstwa rolnego.

Rozszerzenie katalogu mienia, które można było wykorzystać na cele inwestycyjne, nieuchronnie naruszało zasadę restytucji. Jednakże zarówno Traktat Zjednoczeniowy, jak i konstytucja zezwoliły na ograniczenie prawa do zwrotu majątku prawowitym właścicielom w przypadkach koniecznych do zaspokojenia bardziej pilnych potrzeb inwestycyjnych ${ }^{48}$.

\section{ZMIANY WPROWADZONE W 1992 R.}

Pomimo nowelizacji z $1991 \mathrm{r}$. tempo inwestycji sektora prywatnego poprawiło się jedynie marginalnie i rozwój gospodarczy we wschodnich landach nadal był niewystarczający. Przepisy ustawy majątkowej i prawa o szczególnych inwestycjach zachodziły na siebie, dochodziło do kolizji procedur i w związku z tym do przedłużania się postępowań przed organami administracji ${ }^{49}$. Institut für Wirtschaftsforschung Halle (Instytut Badań Gospodarczych w Halle) oszacował całkowitą sumę potencjalnych inwestycji unieruchomionych w procedurach biurokratycznych na około 100 milionów marek niemieckich w samym Berlinie ${ }^{50}$. Dlatego też dokonano ponownych nowelizacji wcześniej wskazanych ustaw w nadziei, że zmiany legislacyjne poprawią sytuację gospodarczą. W lipcu 1992 r. uchwalono kolejną, drugą, nowelizację ustawy majątkowej ${ }^{51}$. Oprócz zmian w prawie majątkowym ustawa ta zastąpiła prawo o szczególnych inwestycjach ustawą o pierwszeństwie inwestycji - Investitionsvorranggesetz ${ }^{52}$. S. 994).

$47 \S 1 \mathrm{a}(3)$ znowelizowanego w 1991 r. prawa o szczególnych inwestycjach (BGB1. 1991 I,

48 Art. 41 (2) Traktatu Zjednoczeniowego i art. 143 (3) konstytucji Niemiec.

49 Por. sytuacje opisane w: M.E. Elling, op. cit., s. 614-615.

50 R. Neubauer, Wege aus der Krise-Wundern dauern länger, „Die Zeit”, 2 kwietnia 1993, s. 7.

51 Das Zweite Vermögensrechtsänderungsgesetz z 14 lipca 1992 r. (VermRÄndG 2), BGB1. 1992 I, S. 1257. Odnośnie do tej nowelizacji zob. więcej: N. Horn, Das Zweite Vermögensrechtsänderungsgesetz und die Verfügbarkeit von Grundeigentum im neuen Bundesgebiet, „Deutsche Zeitschrift für Wirtschaftsrecht"1992, Nr. 8, s. 1-8.

52 Gesetz über den Vorrang für Investitionen bei Rückübertragungsansprüchen nach dem Vermögensgesetz (Investitionsvorranggesetz - InVorG) z 14 lipca 1992 r., BGBl. I, S. 1268. 
Pomimo narastających głosów krytycznych kolejna nowelizacja ustawy majątkowej utrzymała zasadę pierwszeństwa restytucji przed odszkodowaniem. Zasada ta jednak została znacznie osłabiona przez wprowadzenie zasady pierwszeństwa inwestycji nad restytucją. Druga nowelizacja ustawy majątkowej wprowadziła następujące zmiany: uproszczenie procedur związanych $z$ ustaleniem statusu prawnego nieruchomości, uszczelnienie pierwotnego systemu restytucji $\mathrm{w}$ celu uprzywilejowania inwestorów, poprawienie pozycji prawnej inwestorów, ochrona interesów prywatnych właścicieli majątków, w stosunku do których zgłoszono roszczenia o zwrot $^{53}$.

Z uwagi na dużą liczbę wniosków złożonych przez byłych właścicieli i ich spadkobierców termin do zgłaszania roszczeń o zwrot lub odszkodowanie przedłużono do 31 grudnia $1992 \mathrm{r}^{54}$ Termin ten był ostateczny - wszelkie wnioski zgłoszone później podlegały odrzuceniu, a aktualni właściciele majątków, w stosunku do których nie zgłoszono roszczeń windykacyjnych, uzyskiwali niepodważalny tytuł prawny do majątku. Do końca 1992 r. zarejestrowano około 1,2 miliona wniosków restytucyjnych w stosunku do majątków znajdujących się w granicach byłej NRD ${ }^{55}$. Niektóre $z$ wniosków dotyczyły więcej niż jednej nieruchomości, łącznie więc zgłoszono roszczenia wobec ponad 2 milionów nieruchomości, stanowiących w sumie ponad połowę powierzchni byłej $\mathrm{NRD}^{56}$.

\section{PIERWSZEŃSTWO INWESTYCJI}

Istotne zmiany wprowadziła również nowa ustawa o pierwszeństwie inwestycji. Sam tytuł wyraźnie świadczył o zmianie priorytetów polityki reprywatyzacyjnej. Nowa regulacja z powodu swojego skrajnie proinwestorskiego nastawienia kosztem dawnych właścicieli nazwana została „prawem o zniesieniu reprywatyzacji” ${ }^{27}$, gdyż całkowicie odwróciła pierwszeństwo w zakresie postępowań administracyjnych odnoszących się do danego majątku. Postępowanie w sprawie odzyskania nieruchomości musiało zostać zawieszone, jeśli została wszczęta procedura w sprawie wydania zaświadczenia o pierwszeństwie inwestycji ${ }^{58}$. Przed wydaniem

\footnotetext{
53 R. Frank, op. cit., s. 851.

54 § 30 a ustawy majątkowej. Jedynie roszczenia dotyczące majątku ruchomego mogły być zgłaszane o pół roku dłużej - do 30 czerwca 1993 r.

55 H. Schmidt, Uns Deutsche kann der Teufel holen, „Die Zeit”, 24 maja 1991, s. 3. D. Southern podaje liczbę 1,1 miliona wniosków, wskazując, że poza obszarami wiejskimi nie było prawie majątków, w stosunku do których nie zgłoszono roszczeń (idem, Restitution or compensation: The open property question, „German Politics”1993, vol. 2, Issue 3, s. 436).

56 J. Tucker-Mohl, op. cit., s. 17.

57 M. Załęczna, Odzyskanie utraconego mienia, „Nieruchomości” 1998, nr 2, s. 15.

$58 \S 4$ (4) ustawy o pierwszeństwie inwestycji.
} 
tego zaświadczenia organ musiał zawiadomić o toczącym się postępowaniu wnioskującego o restytucję oraz urząd właściwy do rozpatrzenia jego wniosku ${ }^{59}$. Po notyfikacji wnioskodawca miał 2 tygodnie na przygotowanie oficjalnej odpowiedzi i przedstawienie uzasadnionych argumentów na poparcie swoich roszczeń. W okresie 6 tygodni natomiast mógł przedstawić kontrpropozycję planu inwestycyjnego dotyczącego spornego majątku. Przesłuchanie, które co do zasady przysługiwało wnioskodawcy, mogło jednak zostać całkowicie ominięte, jeśli wydłużenie postępowania zagrażało realizacji planu inwestycyjnego inwestora. Dzięki wprowadzonym zmianom inwestor uzyskał znaczną przewagę nad skarżącym, w szczególności jeśli uprzednio skonsultował się z aktualnym posiadaczem majątku (np. Urzędem Powierniczym) w celu opracowania lepszego planu inwestycyjnego, tak aby przygotować się na przesłuchanie wnioskodawcy ${ }^{60}$.

Istotną zaletą nowej ustawy było zebranie wyjątków od zasady restytucji poprzednio rozproszonych $\mathrm{w}$ różnych aktach, uporządkowanie ich i uregulowanie w przejrzysty sposób. Uproszczono także i ujednolicono procedury związane z uzyskaniem zaświadczenia o pierwszeństwie inwestycji ${ }^{61}$. Podobnie jak poprzednie regulacje, ustawa z 1992 r. utrzymała ścisłe ramy czasowe dla uzyskania takiego zaświadczenia - ostateczny termin do złożenia stosownego wniosku przesunięto do końca 1995 r. $^{62}$

\section{ZAKOŃCZENIE}

Proces reprywatyzacji majątku w byłej NRD stanowił jedno z największych wyzwań związanych ze zjednoczeniem Niemiec. Jego podjęcie wymagało znalezienia kompromisu pomiędzy przeciwstawnymi celami oraz konfliktem różnego rodzaju interesów. $Z$ jednej strony podkreślano, iż reprywatyzacja jest moralnym imperatywem, a jej brak oznacza legalizację państwowego bezprawia. $Z$ drugiej strony, osłabiona po okresie socjalistycznych rządów gospodarka wschodnich landów wymagała intensywnego pobudzenia w drodze inwestycji. Rozwiązanie konfliktu tak spornych dóbr i wartości wymagało wprowadzenia skomplikowanych rozwiązań prawnych.

Poprzedni właściciele lub ich spadkobiercy zgłosili roszczenia w stosunku do ponad 2 milionów nieruchomości znajdujących się we wschodnich Niemczech. Status prawny majątków stanowiących ponad połowę powierzchni byłej NRD

\footnotetext{
$59 \S 5$ ustawy o pierwszeństwie inwestycji.

60 R. Frank, op. cit., s. 855.

${ }_{61}$ Zob. więcej na ten temat: V. Jesch, N. Ley, K. Racky, I. Winterstein, B. Kuhn, Investitionsvorrangsgesetz. Kommentar, Berlin-New York 1993, s. 94-123.

$62 \S 4$ (1) ustawy o pierwszeństwie inwestycji.
} 
okazał się niepewny - nie było wiadomo, komu ostatecznie przypadnie własność nieruchomości. Sytuacja ta skutecznie zablokowała inwestycje sektora prywatnego we wschodnich landach. Trudną sytuację gospodarczą stopniowo poprawiały wprowadzane nowelizacje, przyznające przewage potencjalnym inwestorom nad prawami dawnych właścicieli, jednocześnie rozszerzając katalog wyjątków od zasady restytucji.

Gdyby od początku odszkodowanie pieniężne zostało ustalone jako podstawowa forma reprywatyzacji, a restytucja byłaby wyjątkiem, to problemy, z jakimi borykały się wschodnie landy, byłyby prawdopodobnie znacznie mniejsze. Źródłem funduszy na poczet wypłaty odszkodowań mogłyby być dochody ze sprzedaży inwestorom wywłaszczonego uprzednio majątku ${ }^{63}$.

Tempo inwestycji osłabiał też znacząco fakt, że przez długi czas nie było jasnych reguł, według których nastąpić miała wypłata odszkodowania pieniężnego wywłaszczonym podmiotom ${ }^{64}$. Uniemożliwiało to podjęcie prawowitym właścicielom rozsądnej decyzji odnośnie do wyboru metody naprawienia wyrządzonej im szkody: w naturze poprzez restytucję czy też w drodze wypłaty odszkodowania pieniężnego. Zasady odnoszące się do wypłaty odszkodowań określone zostały dopiero w 1994 r. $^{65}$ Uprawnionym przyznano prawo do odszkodowania, kształtującego się jednak dużo poniżej aktualnej wartości rynkowej danego majątku ${ }^{66}$.

W świetle ciągle nieukończonych prac nad polską ustawą dotyczącą wywłaszczonych majątków szczególnie ważne jest prawidłowe ustalenie celów polityki reprywatyzacyjnej. Przykład wschodnioniemieckiej reprywatyzacji pokazuje, iż restytucja w naturze, jakkolwiek wydaje się najsprawiedliwszym środkiem naprawienia dawnych krzywd, może bardzo niekorzystnie wpłynąć na gospodarkę. Polska nie może przecież liczyć na pomoc finansową, jaką otrzymały wschodnie landy. Dlatego musi wykorzystać wszelkie instrumenty stymulujące działalność inwestycyjną podmiotów prywatnych - krajowych i zagranicznych. Wydaje się zatem, że bardziej odpowiednim sposobem wyrównania, przynajmniej częściowo, poniesionego uszczerbku jest naprawienie szkody w drodze wypłaty odszkodowania pieniężnego (ewentualnie przyznania gruntu zamiennego).

63 R. Frank, op. cit., s. 864.

64 Ibidem, s. 863.

65 Gesetz über die Entschädigung nach dem Gesetz zur Regelung offener Vermögensfragen (Entschädigungsgesetz) z 27 września 1994 r. BGB1. 1994 I, S. 2624.

${ }_{66} \mathrm{Na}$ szczególną uwagę zasługuje $§ 7$ Entschädigungsgesetz, który przewidywał progresywną redukcję płatności odszkodowania przekraczającego wartość 10000 marek niemieckich. Zob. R. Heller, O. Quandt, R. Sannwald, Entschädigung- und Ausgleichsleistungsgesetz (EALG). Kommentar, Köln-Berlin-Bonn-München 1995, s. 49-53; P. Zimmermann, Das neue Entschädigungs- und Ausgleichsleistungsgesetz - EALG, München 1995, s. 123-126; P. Gemmeke, Entschädigungs- und Ausgleichsleistungsgesetz, Baden-Baden 1995, s. 93-95. 
W trakcie przygotowywania projektu polskiej ustawy reprywatyzacyjnej warto oprzeć się na wzorach niemieckich regulacji prawnych, zwłaszcza w ich znowelizowanych wersjach. Niezwykle ważne jest ograniczenie możliwości zgłoszenia roszczeń ścisłymi terminami, co pozwoli skrócić stan niepewności prawnej odnośnie do danego majątku ${ }^{67}$. Oczywiście terminy te nie mogą być bardzo krótkie, lecz powinny być tak określone, by zapewnić uprawnionym realną możliwość zgłoszenia roszczeń. Konieczne jest też ustalenie przejrzystych, jednolitych procedur dla weryfikacji i rozpatrywania wniosków reprywatyzacyjnych (odszkodowawczych). Niezbędne jest też określenie od razu - w ustawie reprywatyzacyjnej - jasnych zasad wypłaty odszkodowana i sposobu wyliczenia jego wysokości.

Przeprowadzona $\mathrm{w}$ artykule analiza przepisów dotyczących reprywatyzacji pozwala sformułować wniosek, że niemiecki ustawodawca aktywnie reagował na sytuację ekonomiczną i kształtował nowe reguły gry uczestników życia gospodarczego, nie obawiając się podjęcia kontrowersyjnych decyzji. Uregulowanie tak skomplikowanych kwestii odbywało się w imponującym tempie. Przygotowanie nowelizacji z $1991 \mathrm{r}^{68}{ }^{6}$ zajęło niecałe 4 miesiące - od powołania komisji przygotowującej projekt ustawy po jej uchwalenie przez obie izby parlamentu ${ }^{69}$.

Skorzystanie z doświadczeń niemieckich i wprowadzenie postulowanych rozwiązań pozwoliłoby „ożywić” martwy kapitał spętany więzami niepewności prawnej i skoncentrować wiązkę praw własności w rękach poszczególnych właścicieli, co stanowiłoby istotny impuls dla działalności inwestycyjnej i w efekcie stymulowałoby rozwój gospodarczy kraju. Trudno oprzeć się wrażeniu, że od dwóch dekad polski ustawodawca unika podjęcia trudnych decyzji i odkłada uregulowanie nierozwiązanych kwestii majątkowych.

\section{BIBLIOGRAFIA}

Elling M.E., Privatization in Germany: A Model For Legal and Functional Analysis, „Vanderbilt Journal of Transnational Law" 1992, vol. 25, Issue 4.

Fieberg G., Reichenbach H., Einführung, [w:] Vermögengesetz, München 2001, s. XIXXXI.

Försterling W., Rechts der offenen Vermögensfragen, München 1993.

67 Taką regulację przyjął zresztą polski ustawodawca odnośnie do mienia zabużańskiego. Zgodnie $z$ art. 5 wyżej cytowanej ustawy z dnia 8 lipca 2005 r. potwierdzenie prawa do rekompensaty następowało na wniosek osoby ubiegającej się o potwierdzenie tego prawa, złożony nie później niż do dnia 31 grudnia 2008 r. Ustawodawca dał więc uprawnionym ponad 3 lata na zgłaszanie roszczeń.

68 Cytowana wyżej ustawa: Das Gesetz zur Beseitigung von Hemmnissen bei der Privatisierung von Unternehmen und zur Förderung von Investitionen z 22 marca 1991 r.

${ }_{69}$ M. E. Elling, op. cit., s. 611. 
Frank R., Privatization In Eastern Germany: A Comprehensive Study, „Vanderbilt Journal of Transnational Law" 1994, vol. 27.

Frege C.M., Social Partnership at Work. Workplace relations in post-unification Germany, London-New York 1999.

Gemmeke P., Entschädigungs- und Ausgleichsleistungsgesetz, Baden-Baden 1995.

Götz M., Niemcy w przededniu 20 rocznicy zjednoczenia - wciq̨ż różnice?, „Biuletyn Instytutu Zachodniego" 2009, nr 28.

Heller R., Quandt O., Sannwald R., Entschädigung-und Ausgleichsleistungsgesetz (EALG). Kommentar, Köln-Berlin-Bonn-München 1995.

Horn N., Das Zweite Vermögensrechtsänderungsgesetz und die Verfügbarkeit von Grundeigentum im neuen Bundesgebiet, Deutsche Zeitschrift für Wirtschaftsrecht 1992, Nr. 8.

Jesch V., Ley N., Racky K., Winterstein I., Kuhn B., Investitionsvorrangsgesetz. Kommentar, Berlin-New York 1993.

Leo H., \$ 3 a Vermögensgesetz - Vorfahrt für Investitionen?, „Der Betrieb”, 19 lipca 1991 r., Heft 29.

Mostert H., Lost Information and Competing Interests In Restoring Germany`s Dispossessed Property - The Recent Decision of the German Federal Administrative Court, „German Law Journal" 2004, vol. 1.

Neubauer R., Wege aus der Krise-Wundern dauern länger, „Die Zeit”, 2 kwietnia 1993 r.

Randelzhofer A., Tomuschat C., State Responsibility and the Individual. Reparation in Instances of Grave Violations of Human Rights, Cambridge 1999.

Rodenbach H.J., Löffler O., Entschädigungen und Ausgleichsleistungen für Vermögensverluste in ehemaligen DDR und der SBZ, Berlin 1995.

Schäuble W., Der Vertrag. Wie ich über die deutsche Einheit verhandelte, Stuttgart 1991.

Schmidt H., Uns Deutsche kann der Teufel holen, „Die Zeit”, 24 maja 1991.

Southern D., Restitution or compensation: The open property question, "German Politics” 1993, vol. 2, Issue 3.

Southern D., Restitution or Compensation: The Property Question, [w:] Transitional Justice, red. N.J. Kritz, Washington 1995, s. 644 i n.

Stack H. M., The "Colonization" of East Germany?: A Comparative Analysis of German Privatization, „Duke Law Journal” 1997, vol. 46.

Tucker-Mohl J., Property Rights and Transitional Justice: Restitution In Hungary and East Germany, http://ocw.mit.edu/courses/urban-studies-and-planning/11-467j-property-rights-in-transition-spring-2005/ projects/jtuckermohlfinal.pdf.

Vitzthum W.G., März W., Restitutionsausschluss, Berlin 1994.

Załęczna M., Odzyskanie utraconego mienia, „Nieruchomości” 1998, nr 2.

Zimmermann P., Das neue Entschädigungs- und Ausgleichsleistungsgesetz - EALG, München 1995. 


\section{RESTITUTION, COMPENSATION, OR INVESTMENT? \\ - REPRIVATISATION OF GERMAN DEMOCRATIC REPUBLIC PROPERTY}

SUMMARY

The article illustrates the process of the restitution of property within the boundaries of the former GDR. It presents the initial arrangements in this regard between the two German states, concluded in Joint Declaration and Unification Treaty, which provided an obligation to return assets expropriated by the state to their rightful owners or their heirs. This principle of restitution was subsequently developed in the Property Law of 1990. In order to stimulate investment, further legislation, however, introduced exceptions to this rule, giving finally priority to investors over former owners rights. The aim of this article is to draw a conclusion from German experiences and to find clues for the regulation of still unresolved restitution issue in Poland. 


\section{INTEGRACJA I DEZINTEGRACJA WSEKTORZE FINANSOWYM}


